DOI 10.34883/PI.2021.12.4.007

УДК 159.922 .767

Danilova Y.', Danilova M. ${ }^{2}$

${ }^{1}$ Herzen State Pedagogical University of Russia, Saint-Petersburg, Russia

${ }^{2}$ Saint Petersburg State University, Saint-Petersburg, Russia

Данилова Ю.Ю.' , Данилова М.В. ${ }^{2}$

${ }^{1}$ Российский государственный педагогический университет имени А.И. Герцена, Санкт-

Петербург, Россия

${ }^{2}$ Санкт-Петербургский государственный университет, Санкт-Петербург, Россия

\title{
The Impact of Family Deprivation on Development of Self-Trust in a Sample of Russian Adolescents
}

\author{
Влияние семейной депривации на развитие доверия \\ к себе на выборке российских подростков
}

Abstract

Introduction. Trust in general and self-trust in particular is an essential condition for the development and psychological well-being of an individual. The article is devoted to the specifics of self-trust in adolescents, who are brought up in conditions of family deprivation.

Purpose. To study and compare the level of self-trust among adolescents that live in parental families and orphanages, and also to study the influence of having a family on self-trust among respondents.

Materials and methods. A reflexive questionnaire of the level of self-trust by Skripkina was used to analyze the level of self-trust. It reflects the degree of self-trust in various areas of life that are important for adolescents. Adolescents from parental families and orphanages were the sampling unit. A total of 176 Russian adolescents were surveyed ( 82 males and 94 females); 97 of them live in parental families ( 43 males and 54 females), 79 adolescents are brought up in an orphanage (39 males and 40 females).

Results. The adolescents brought up in conditions of family deprivation, experience difficulties in self-trust manifestation in those areas of life that are unresolved tasks of the previous age: relationships with parents, in the educational and intellectual fields. The research clearly shows the influence of family presence on the development of self-trust in adolescents.

Conclusion. Our data indicate a high influence of the family factor on the development of selftrust, and, as a consequence, on the lack of it in adolescents brought up in conditions of family deprivation.

Keywords: family, deprivation, adolescence, self-trust, social situation of development.

Резюме

Введение. Доверие в целом и доверие к себе в частности - важное условие корректного развития и психологического благополучия человека. В статье раскрываются особенности доверия к себе у подростков, воспитывающихся в условиях семейной депривации.

Цель. Изучить и сравнить уровень доверия к себе подростков, проживающих в родительских семьях и детских домах, а также изучить влияние наличия семьи на доверие к себе в ситуации семейной депривации. 
Материалы и методы. Для анализа уровня доверия к себе мы использовали рефлексивный опросник уровня уверенности в себе Т.П. Скрипкиной. Он отражает степень доверия к себе в различных сферах жизни, значимых для подростков. В исследовании приняли участие подростки из родительских семей и детских домов. Всего было обследовано 176 российских подростков (82 юноши и 94 девушки), из них 97 проживают в родительских семьях (43 юноши и 54 девушки), 79 подростков воспитываются в детских домах (39 юношей и 40 девушек).

Результаты. Подростки, воспитанные в условиях семейной депривации, испытывают трудности в проявлении доверия к себе в тех сферах жизни, возрастные задачи которых должны были быть решены на предыдущих этапах: взаимоотношения с родителями, образовательная и интеллектуальная сферы. Исследования ясно показывают влияние присутствия семьи на развитие доверия к себе у подростков.

Выводы. Наши данные свидетельствуют о высоком влиянии семейного фактора на развитие доверия к себе и, как следствие, на его недостаточную выраженность у подростков, воспитываемых в условиях семейной депривации.

Ключевые слова: семья, депривация, подростковый возраст, доверие, социальная ситуация развития.

\section{- INTRODUCTION}

In socio-economic conditions of modern world, alarming trends are manifested acutely: an increase in social orphans, street children, who exhibit deviant, anti-social behavior (substance abuse, alcoholism, theft, etc.). In this connection, there is a need to understand the nature of problems of these children and adolescents. The main factors of personal development are, of course, the features of family education and family deprivation [33]. It is impossible to analyze and solve many social issues related to the behavior and mental development of younger generation without taking into account the presence or absence of a family, the nature of upbringing and other socio-demographic characteristics.

Family deprivation and its consequences. Family is understood as the primary institute of social interaction and a provider of indispensable support for the maintenance of physical and psychological integrity, exercising the functions of protection, affection and social formation [11]. As emphasized by Biasoli-Alves [5], family corresponds to the social group that exerts a significant influence on the life of people, being seen as a complex organization, inserted in a social context with which it maintains constant interaction. In this regard, Baptista et al. [3] found that perceptions of affection, adaptation and autonomy from the family context were correlated with the increase in the number of people perceived as supportive. The more affection the individual receives early in life, the greater will be his willingness to face and overcome stressful events, since affection is developed from infancy and can protect children from internal and external stressors [34], substance abuse, and depression [27]. Andolfi, Ângelo, Nicolo-Corigliano and Menghi [1] argue that it is through the family that the individual develops himself psychologically. He or she gradually passes through several stages, from a nondifferentiation state, in which he still perceives himself in a process of symbiosis, to a state of 
individualization, in which he becomes independent, that is, an individual ready to live in society and to take action in the face of joys and challenges.

Deprivation is a psychic state of an individual that has arisen under such life circumstances where the person is not given the opportunity to satisfy his vital needs sufficiently and for a long time [2]. All the variety of emotions, feelings, knowledge, life experiences a child receives in the process of education from parents. Education in orphanages does not facilitate the creation for receiving a real experience of emotional relationships and interactions within the family by children. This, undoubtedly, leads to the adverse factors of personal development and socialization [23]. Maternal deprivation is a powerful pathogenic factor for a number of serious disorders in personal development. The effects of maternal deprivation are most pronounced in children from orphanages [10]. Researches show the specific, qualitatively different picture of personal development such children and adolescents. They often show distortions of personality development in emotional, communicative, motivational spheres, violation of sexual identification, immaturity of value-semantic orientations etc. $[19,25]$. Maternal deprivation and a lack of positive experience of family relationships leads to the formation of self-doubt, uncertainty about the future, hinders the development of communicative personal potential and impede social integration [24].

Pupils from orphanages are often characterized by isolation, distrust to others with high suggestibility, concern, emotional instability in stressful situations. Breach of trust and emotional connection with parents, especially with mother, negatively affects the development of intellectual abilities. Children, experiencing the effects of maternal deprivation, have a low level of emotional intelligence, they are contradictory, they feel guilty that their parents do not like them. Later, the child loses self-esteem, there is a violation of the identification of his own needs, difficulties in determining the boundaries of his personality, emotional dependence, fear of abandonment [25]. Adolescents, suffering from family deprivation, show rudeness, emotional coldness, indifference, callousness towards loved ones, they are lethargic, apathetic, indifferent, aggressive and often exhibit antisocial behavior [2].

Trust and self-trust from childhood to adolescence. The studies of J. Bowlby [8] emphasize that the situation of psychic deprivation and, in particular, the deprivation of trust, leads to a number of often irreversible mental health problems. He sees the age of up to 5 years under the condition of a long break with his mother (from six months) as the key period affecting the distortion in personal development [8]. That is, trust begins to form in early childhood and represents the basic trust of a person, formed on the basis of attachment to a mother or a significant adult, on the basis of which self-trust and trust towards others are later built. Trust is the foundation of a child's positive self-reliance, confidence, initiative, curiosity, etc. [18, 20, 22]. Basic trust to the world, which is impossible under conditions of maternal deprivation, affects the ability to make friendship and love, to establish deep relationships with other people [16]. The concept of trust is mostly researched in modern Russian psycholgy by Skripkina [30]. The author identifies three components in the structure of trust: trust to the world, self-trust, and trust to other people. These components of trust do not function separately from 
each other, and a violation of the development of one of them leads to disharmonious development of others. So, trust is an independent sociopsychological phenomenon that performs basic functions in the life of an individual and acts as an integral condition for holistic interaction [17, 31]. Self-trust is a relationship to one's own subjectivity. The results of previous studies show that the age between 10 and 12 years is extremely significant in the development of self-trust and its separation from interpersonal trust. Self-trust is an extremely important source of reflection, which leads to the realization of the discrepancy between the desired, required and possible [30]. The way a child solves such intrapersonal contradictions reflects the level of severity of self-trust. Self-trust is a key condition for full self-control, it is included in the structure of the ability to anticipate the results of activities and actions, determines the level of adequacy of behavior.

The relevance and significance of our study is explained by serious interest to the problem of trust in the modern world, while at the same time, self-trust as a part of it is not fully represented in scientific literature. The studies were mainly conducted on adult samples. Correlations of self-trust with social situation of development and socio-demographic characteristics are also not enough investigated in adolescence.

Thus our main hypotheses is that family deprivation influences negatively on the development of self-trust in adolescence.

\section{- PURPOSE}

To determine the importance of having a family for building self-trust in adolescence.

Research objectives: 1 ) to study the level of self-trust in adolescents, experiencing the effects of family deprivation; 2 ) to establish correlations of self-trust in adolescents with socio-demographic characteristics (family structure, siblings, age); 3 ) to determine the influence of family structure on self-trust in adolescence.

\section{- MATERIALS AND METHODS}

Setting and participants. The sample was recruited from Russian schools (family adolescents) and orphanages (family deprived adolescents). The study involved 176 adolescents aged 15-16 years (82 males and 94 females), 97 living in parental families (43 males and 54 females), 79 being brought up in orphanages ( 39 males and 40 females).

Children from orphanages are so called "social orphans" - these are children whose parents were unable to keep them due to either financial or mental health problems, etc.

Instruments. The reflective questionnaire of self-trust by Skripkina [29] used to measure the level of self-trust. The original version of the questionnaire contains 11 scales that reflect the vital areas of adults' life: in work, in intellectual activity, in the ability to build relationships with colleagues, friends, in the family, with children, the elderly, representatives of the opposite sex, as well as in household skills and the ability to spend leisure time. Since the respondents of our research are adolescents, we have modified several scales, taking into account significant areas of life during this period. It was required to mention the level of self-trust in 11 areas significant for adolescents: educational and intellectual activities, household 
skills, the ability to build relationships with friends, parents, family, teachers, younger pupils, children, members of the opposite sex and the ability to spend leisure time. Respondents rated their level of self-trust on a scale from 1 (I do not trust myself at all) to 5 (I trust myself completely). We also calculated the overall level of self-trust on all 11 scales, the maximum level of self-confidence is 55 points. Adolescents from orphanages also noted the level of self-trust in their relationships with parents, since they knew their parents.

We used a biographical questionnaire, including questions about the composition of the family, age, siblings, parenting styles (not strict strict) to study the socio-demographic characteristics of adolescents. The composition of the family in this case refers to the absence of parents, one or two parents.

Procedure. Students were interviewed during the study time, and the tools provided corresponded to the broader scope of the project to which this study belongs: "Trust in older adolescence in connection with personal characteristics and social situation of development". The study was approved by Research Ethics Committees of the co-authors' University and by the Ministry of Education. The adolescents were assured that all information they would pass on would remain confidential and they were asked to answer questions individually and with complete freedom. Participants took about 60 minutes to complete the questionnaires.

Statistical analysis. The data was coded and computed using the statistical package for social sciences (SPSS) 20.0 version. The descriptive statistics were computed for self-trust variables. To determine the reliability of intergroup differences, the Student's T-test was used. To study the correlations between the parameters under study, a Pearson correlation analysis was used. Influence of family structure on self-trust was studied using regression analysis.

\section{- RESULTS}

The study of the level of self-trust shows that adolescents, living in families, have a greater degree of self-trust in the ability to spend leisure time (4.38), in educational (4.25) and intellectual activities (4.34), in relationships with parents (4.24) and teachers (4.21). The lowest points were obtained by indicators of self-trust in relations with representatives of the opposite sex (3.73) and primary school pupils (3.86). Adolescents from orphanages show self-trust in their relationships with friends (4.34) and young children (4.15), least of all they trust themselves in the ability to spend leisure time (3.53), build relationships with teachers (3.64) and parents (3.26), in educational (3.43) and intellectual activity (3.42). Significant differences were found between groups, divided by the social situation of development, in the level of self-trust in educational and intellectual activity, in the ability to spend leisure time, in relations with parents (at $p<0.001)$ and teachers (at $p<0.05$ ) (table 1).

To establish the association between self-trust and socio-demographic characteristics correlation analysis was applied. The correlation constellation consists of 14 connections (13 positive and 1 negative), most of which formed the factor of family composition (7 connections). Thus, with an increase in the amount of family members (both parents), a higher level 
Table 1

Self-trust and significant differences in its manifestation in the groups divided by social situation of development

\begin{tabular}{|c|c|c|c|c|}
\hline Self-trust parameters & Family factor & M & SD & $\mathbf{p}$ \\
\hline \multirow{2}{*}{ In intellectual activity } & Family & 4,34 & 0,851 & \multirow{2}{*}{$0,001^{* *}$} \\
\hline & Orphanage & 3,42 & 1,18 & \\
\hline \multirow{2}{*}{ In educational activity } & Family & 4,25 & 0,688 & \multirow{2}{*}{$0,001^{* *}$} \\
\hline & Orphanage & 3,43 & 1,19 & \\
\hline \multirow{2}{*}{ In relationships with parents } & Family & 4,24 & 0,657 & \multirow{2}{*}{$0,000 * *$} \\
\hline & Orphanage & 3,26 & 1,052 & \\
\hline \multirow{2}{*}{ In relationships with teachers } & Family & 4,21 & 1,025 & \multirow{2}{*}{$0,003^{*}$} \\
\hline & Orphanage & 3,64 & 0,931 & \\
\hline \multirow{2}{*}{ In the ability to spend leisure time } & Family & 4,38 & 0,988 & \multirow{2}{*}{$0,001^{* *}$} \\
\hline & Orphanage & 3,53 & 1,426 & \\
\hline
\end{tabular}

Note: $M$ - mean, SD - standard deviation, ${ }^{*} p<0.05,{ }^{* *} p<0.001$.

of self-trust is found in educational and intellectual activity, in relations with primary school pupils, parents, teachers, friends ( 6 connections at $p<0.001)$ and in the family $(p<0.05)$. The age factor also found 4 direct relationships with self-trust in intellectual activity and the ability to spend leisure time at $p<0.001$ and in educational activities and in relations with parents at $p<0.05$. Thus we can say that with increasing age, adolescents trust themselves more in being successful in educational and intellectual activities, in their ability to communicate with parents and diversify their leisure activities. The presence of siblings revealed 3 positive connections and 1 negative. Thus, with an increase in the number of siblings, self-trust in the ability to communicate with young children $(p<0.001)$, representatives of the opposite sex and teachers $(p<0.05)$ increases, but self-trust in family relationships decreases $(p<0.05)$ (Figure).

We conducted a regression analysis, where the dependent variable was the overall level of self-trust, and the independent variables were sociodemographic characteristics of adolescents. Thus, for the indicator of the general level of self-trust in the group of adolescents from an orphanage, we obtained a regression model that explains $68 \%$ of the total variance. Age $(\beta=0.298, p=0.001)$, the presence of siblings $(\beta=0.199, p=0.018)$, the assessment of upbringing as more strict $(\beta=0.282, p=0.001)$ act as positive predictors of the overall level of self-trust (Table 2 ).

For the indicator of the general level of self-trust in the group of adolescents from families, we obtained a regression model that describes

Table 2

Data from regression analysis of the general level of self-trust and socio-psychological factors in the groups of adolescents from orphanages

\begin{tabular}{|c|c|c|c|c|}
\hline \multirow{2}{*}{ Factors } & \multicolumn{4}{|c|}{ Adolescents from orphanages } \\
\hline & $\mathbf{R}$ & Parameters & $\beta$ & $\mathbf{P}$ \\
\hline \multirow{3}{*}{ Overall level of self-trust } & \multirow{3}{*}{0,68} & Age & 0,298 & 0,001 \\
\hline & & Siblings & 0,199 & 0,018 \\
\hline & & Strict parenting style & 0,282 & 0,001 \\
\hline
\end{tabular}




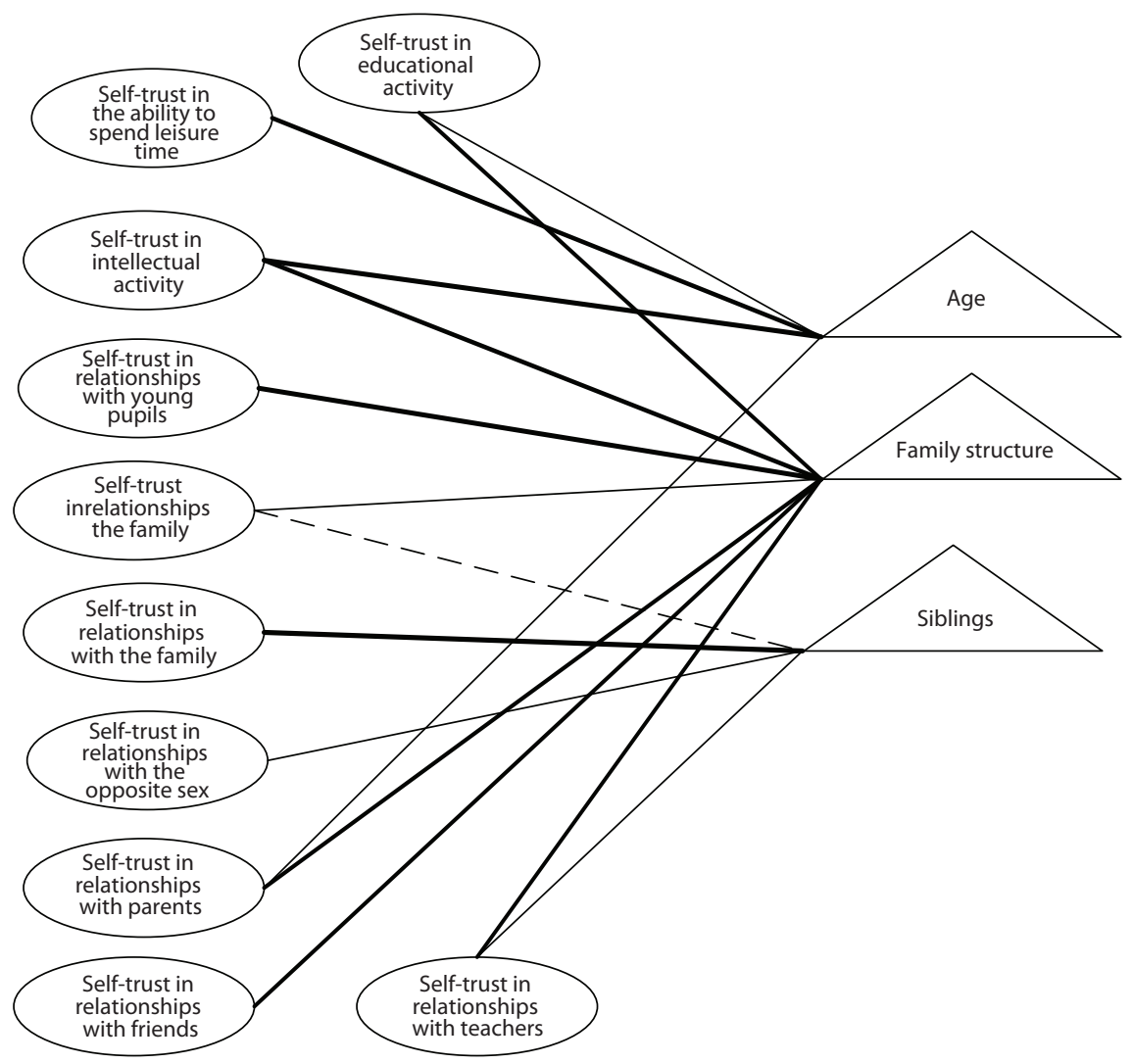

\section{Correlations of self-trust with socio-demographic characteristics}

Notes: $\mathrm{p}<0.05, \mathrm{p}<0.001$.

$74 \%$ of the total variance. Assessment of parenting as more strict $(\beta=0.227$, $p=0.007$ ) is positive predictor of self-trust (Table 3 ).

\section{- DISCUSSION}

The study of self-trust in various types of life activities of adolescents allowed us to find out that most of all adolescents show self-trust in their relationships with friends, in the family and in their ability to choose leisure activities, which corresponds to the content of the tasks of this period in establishing intimate relationships. This is also consistent with the notion that the earliest form of self-trust is trust in relationships with close people,

\section{Table 3}

Data from regression analysis of the general level of self-trust and socio-psychological factors in the groups of adolescents from families

\begin{tabular}{|l|l|l|l|l|}
\hline \multirow{2}{*}{ Factors } & \multicolumn{4}{l|}{ Adolescents from families } \\
\cline { 2 - 5 } & R & Parameters & $\boldsymbol{\beta}$ & P \\
\hline Overall level of self-trust & 0,82 & Strict parenting style & 0,547 & 0,001 \\
\hline
\end{tabular}


which helps to establish attachment and is an indispensable condition for positive development [12]. At the same time adolescents experience the greatest difficulties in trusting themselves in relations with the opposite sex, younger schoolchildren and teachers. Since adolescence is a transition period from childhood to adulthood, these spheres of relationships undergo changes and are rebuilt. Elements of a more adult perception and behavior are included in relationships with the opposite sex; relationships with younger ones also undergo changes, as adolescents move away from this group and already do not identify with it; relationships with teachers require a transition to a different level of interaction. These changes, on the one hand, lead to growth of age, including the sphere of self-trust, and on the other hand, lead to difficulties in the formation of these innovations. At the same time, these general patterns of self-trust in our study differ depending on the social situation of development. A study of the impact of social situations on adolescents' development revealed that orphaned adolescents have the lowest indicators of self-trust in the educational and intellectual spheres, in relations with parents and teachers, and in their leisure choices. Adolescents living with their families have the highest rates in all areas of self-trust. These results partially correspond to the data available in the literature, which confirm a varying degree of self-trust in connection with the conditions that the surrounding world provides. In the study of Zaripova [35] there is a violation of trusting relationships as a manifestation of the traumatic experience of orphans. Orphaned adolescents have almost no trusting relationships. In relation to other people, they often show distrust and an expectation of difficulties. Along with this, studies indicate that only $12.5 \%$ of children from orphanages are not subject to deprivation of trust, which means that they have the opportunity to build trustful social relationships. In the remaining $87.5 \%$, along with the deprivation of trust, the value attitude towards oneself is not formed, which is expressed in the absence of self-trust. Also, low indicators of self-trust in the ability to build relationships with teachers and in educational activities in orphaned adolescents can be explained by the following: in communication and educational activities they are characterized by positive motivation in relation to an adult (teacher, educator). It is based on the lack of communication with adults and, as a result, overvaluation of this communication. This does not contribute to the formation and constructive development of educational activities and often even interferes with the normal course of this process. The child wants too much to be accepted by an adult, to earn his personal attention, approval, which prevents from assimilating the necessary knowledge [4]. However, in addition to family deprivation as a whole, there are its components: maternal and paternal deprivation. In the case where the reason for the absence of one of the parents is divorce, children experience a serious psychological shock. This can lead to disruption of the child-parent relationships, which undoubtedly affects the manifestations of trust and self-trust. And since trust is the basis for the successful development of the personality, this can lead to problems with communication and mental health, conflicts and distrust of others, misunderstanding and self-doubt in future. The psychological trauma caused to a child by the divorce can manifest itself as serious problems in adolescence. Researchers note that adolescents raised in divorced families have low self-esteem [9]. According to Figdor [15], in 
adolescent boys with low self-esteem, fathers are often inattentive to them and do not trust in a child. In our study we see the consequences of family deprivation in adolescents from orphanages: trauma of separation from the family, deprivation of parental influence can act as a factor that violates the formation of self-trust in all spheres of life, which in turn leads to violations in the formation of personality.

According to the correlation analysis, socio-demographic characteristics are correlated with the parameters of self-trust in all areas of adolescent's life, therefore, the importance of the family in this matter becomes obvious. The role of good relationships with parents in different areas of life has been extensively researched: in the formation of self-esteem [7], identity [26], interpersonal trust and subjective feeling of wellbeing etc [28]. Our research shows that composition of the family found positive relationships with selftrust in the areas of building intimate-personal relationships with friends, transformation of relationships with parents and younger ones, as well as self-trust in educational and intellectual terms. These results correspond to the data available in the literature, that the provision and receipt of support from family members are fundamentally beneficial for physical and psychological processes [3, 32].

The results of the regression analysis confirm the data of correlation analysis. A common positive predictor of self-trust for both groups was the factor of strict parenting style. Probably, adolescents understand by severity a moderate attention to their life. However, additional positive predictors of self-trust were found in the group of adolescents from orphanages: age and the presence of siblings. The role of age as a predictor of self-trust in adolescents from an orphanage, apparently, is due to the later maturation of the personality in an orphanage. The role of siblings among adolescentsorphans proves once again the importance of family in showing self-trust.

Thus, it can be clearly seen that the family structure and characteristics of upbringing are important predictors for adolescents without a family. Probably, in the group of family adolescents, there are other personal or social factors that influence self-trust, which can be studied in further researches.

\section{- CONCLUSIONS}

The results of the study expand the theoretical knowledge base of developmental psychology, psychology of adolescence, enrich the data of psychological literature on such an important phenomenon in the modern world as trust. The results of this research may be a prerequisite for further study of predictors of self-trust and social trust in adolescence, taking into account the importance of family relationships and the presence of the family as the main social institution of child and adolescent development. Also the study makes it possible to formulate a number of recommendations. In the context of raising children and adolescents outside the parental families, it is necessary to seek all the possibilities of maintaining the connection and constructive social and normative relations of adolescents with their possible relatives or parents and to promote the establishment of relations of trust between them. Our results can be used to build training programs for teachers, educators, psychologists and people directly working with family and orphans. 


\section{Conflict of interest. None declared. \\ Contribution of authors: research concept and design, data collection, processing, writing of the text - Danilova Y.; concept and design of the study, editing - Danilova M.}

\section{- REFERENCES}

1. Andolfi M., Ângelo C., Nicolo-Corigliano A.N., Menghi P. (1994) O indivíduo e a família: Dois sistemas em evolução. Por trás da Máscara familiar, vol. 2, pp. 17-39.

2. Antilogova L.N., Fedorova N.V. (2006) Deprivacija $v$ sem'je kak factor delinkventnogo povedenija podrostkov [Family deprivation as a factor of delinquent behavior in adolescents]. Omskij nauchnij vestnik, vol. 3 (36), pp. 259-262.

3. Baptista M.N., Rigotto D.M., Cardoso H.F., and Rueda F.J.M. (2012) Soporte social, familiar y autoconcepto: relación entre lós constructos. Psicología desde el Caribe, vol. 29(1), pp. 1-18.

4. Berezin S.V. (2003) Sotsial'noe sirotstvo: deti i roditeli [Social orphanhood: children and parents]. Samara: Izd-vo Univers grupp, 52 p. (In Russian)

5. Biasoli-Alves Z.M.M. (2004) Pesquisando e intervindo com famílias de camadas diversificadas. Pesquisando a família: olhares contemporâneos, vol. 3, pp. 91-106.

6. Bolnov O.F. (2001) Novaja ukritost'. Problema ekzistencializma. Vvedenije [New shelter. The problem of existentialism. Introduction] Filosofskaja misl', vol. 2 , pp. 137-145.

7. Borisova M.M., Gurieva S.D. (2017) Formirovanije social'nih predstavlenij o doverii v podrostkovom vozraste [The formation of social ideas of trust in adolescence]. Sovremennije issledovanija social'nih problem, vol. 8 (2), pp. 20-39. Available at: https://doi: 10.12731/2218-7405-2017-2-20-39

8. Bowlby J. (2003) Privjazannost' [Affection]. M.: Gardariki, 480 p. (In Russian).

9. Buyanov M.I. (1988) Rebenok iz neblagopoluchnoj sem'ji: zapiski detskogo psihiatra: kniga dlya uchitelej i roditelej [A child from a dysfunctional family: Notes by a child psychiatrist: A book for teachers and parents]. M.: Prosveshenije, 207 p. (In Russian).

10. Bywaters P., Brady G., Sparks T., Bos E. (2016) Inequalities in child welfare intervention rates: the intersection of deprivation and identity. Child \& Family Social Work, vol. 21, pp. 452-463. doi:10.1111/cfs.12161

11. Campos E.P. (2004) Suporte Social e Família. J. Mello Filho, vol. 6, pp. 141-161.

12. Erikson E. (1963) Childhood and Society (2nd ed.). New York: W.W. Norton \& Company, 445 p.

13. Gideon K. (2013) Adopted children from the former Soviet Union. Are they at risk of fetal alcohol spectrum disorder. Canadian Family Physician, vol. 59 (10), pp. 1063-1064.

14. Fernandes A.O., Oliveira-Monteiro N.R. (2016) Psychological indicators and perceptions of adolescents in residential care. Paidéia, vol. 26(63), pp. 81-89. doi:10.1590/1982-43272663201610.

15. Figdor G. (1995). Deti razvedennykh roditeley: mezhdu travmoy i nadezhdoy [The Children of Divorced Parents: between Trauma and Hope]. Moscow: Nauka, 376 p. (In Russian).

16. Izard K.E. (2011). Psihologija emocij [Psychology of emotions]. SPb.: Piter, 464 p. (In Russian)

17. Kupreichenko A.B. (2008) Psihologija doverija I nedoverija [Psychology of trust and mistrust] M.: Institut psihologii RAN, 569 p. (In Russian)

18. Ledloff J. (2003) Kak virastit rebenka schastlivim. Princip preemstvennosti [How to grow a child happy. A principle of continuity]. M.: Genezis, 230 p. (In Russian).

19. Machnach A.V., Prokhojan A.M., Tolstyh N.N. (2015) Problema sirotstva v sovremennoi Rossii: psihologicheskij aspekt [The Problem of orphanhood in Modern Russia: psychological aspect]. M.: IP RAN, 670 p. (In Russian).

20. Maslow A. (2011). Motivacija I lichnost' [Motivation and personality]. SPB.: Piter, 400 p. (In Russian).

21. Merz E.C., McCall R.B. (2010) Behavior problems in children adopted from psychosocially depriving institutions. Journal of Abnormal Child Psychology, vol. 38(4), pp. 459-70. Available at: https://doi.org/10.1007/s10802-009-9383-4.

22. Osorina M.V. (2010) Sekretnij mir detej v prostranstve mira vzroslih [Children's secret world in adults' world space]. SPb.: Piter, 448 p. (In Russian).

23. Rashmi U., Seema S. (2018) A study of self-esteem and its relationship with the adjustment of orphan age-reared, single parent family-reared and intact family-reared adolescents. International Journal of Educational Science and Research (IJESR), vol. 8(2), pp. 41-50.

24. Shafiq F., Haider S.I., ljaz S. (2020) Anxiety, Depression, Stress, and Decision-Making Among Orphans and Non-Orphans in Pakistan. Psychol Res Behav Manag., vol. 13, pp. 313-318. Available at: https://doi.org/10.2147/PRBM.S245154.

25. Prikhozhan A.M., Tolstykh N.N. (2007) Psichologija sirotstva [Psychology of Orphanhood]. SPb: Piter, 413 p. (In Russian).

26. Sandhu D., Singh B., Tung S., Kundra, N. (2012) Adolescent Identity Formation, Psychological Well-being, and Parental Attitudes. Pakistan Journal of Psychological Research, vol. 27(1), pp. 89-105.

27. Santander S.R., Zubarew T.G., Santelices L.C., Argollo P.M., Cerda J.L., Bórquez M.P. (2008) Influencia de la familia como factor protector de conductas de riesgo en escolares chilenos. Revista Médica de Chile, vol. 136, pp. 317-324. Available at: https://doi: 10.4067/ S0034-98872008000300006.

28. Smetana J. (2010) The role of trust in adolescent-parent relationships: To trust you is to tell you. Interpersonal Trust during Childhood and Adolescence, 3, pp. 223-246. Available at: htpps://doi:10.1017/СBO9780511750946.011.

29. Skripkina T.P. (2008) Doverije kak factor social'nogo razvitija I stanovlenija subjektnosti v detskom vozraste [Trust as a factor of social development and formation of subjectivity in childhood]. Chelovek. Soobschestvo. Upravlenije, vol. 4, pp. 64-73.

30. Skripkina T.P. (2000) Psihologija doverija: uchebnoje posobije dlya stud.vissh. ped. zavedenij [Psychology of trust: textbook for students of higher educational institutions]. M.: Academy, 264 p. (In Russian).

31. Skripkina T.P. (2006) Doverije v social'no-psihologicheskim vzaimodejstvii [Trust in social-psychological interaction]. Rostov n/D: Yuanij federal'nij universitet, 392 p. (In Russian).

32. Souza M.S., Baptista M.N. (2008) Associações entre suporte familiar e saúde mental. Psicologia e Argumentação, vol. 26 (54), pp. $207-215$.

33. Umanskaya E.G. (2013) Razvitije lichnosti v uslovijah deprivacii [Personality development in conditions of deprivation]. M.: Prometej, 145 p. (In Russian).

34. Weinman M.L., Buzi R., Smith P.B., Mumford D.M. (2003) Associations of family support, resiliency, and depression symptoms among indigent teens attending a family planning clinic. Psychological Reports, vol. 93(1), pp. 719-31. Available at: https://doi: 10.2466/ pr0.2003.93.3.719.

35. Zaripova Y.R. (2008) Narushenije doveritel'nyh otnoshenij kak projavlenije travmaticheskogo opita podrostkov-vospitannikov detskogo doma [Violation of trust relationships as a manifestation of the traumatic experience of adolescent children in orphanages]. Vestnik Sankt-Peterburgskogo Universiteta, vol. 12(1), pp. $252-257$.

Submitted/Подана: 20.01.2021

Accepted/Принята: 19.10.2021

Contacts/Контакты: yuliyadanilowa@gmail.com,dan_m@mail.ru 